\title{
Novos rumos nas políticas públicas de saúde mental no Brasil
}

Vivemos um momento único no campo das Políticas Públicas de Saúde Mental no país. Finalmente, após mais de uma década tramitando no Congresso Nacional, a Lei no 3.657/89 foi aprovada e sancionada pelo Presidente da República, no dia 6 de abril de 2001. Esta lei dispõe sobre a proteção e os direitos das pessoas portadoras de transtornos mentais e redireciona o modelo assistencial em saúde mental.

Paralelamente à aprovação da lei, comemoramos no dia 7 de abril o Dia Mundial da Saúde, este ano com o tema Cuidar Sim, Excluir Não. Este dia foi marcado por uma série de eventos em todo o país, como resultado do empenho de estados e municípios na construção de uma Política de Saúde Mental equânime, inclusiva, extra-hospitalar e de base comunitária.

É neste contexto que surge um forte colegiado de coordenadores estaduais e municipais, comprometidos com a criação de condições técnicas e políticas que garantam o direito ao tratamento e à organização de uma rede de atenção integral à saúde, através de dispositivos sanitários e sócio-culturais que integram várias dimensões da vida do indivíduo.

Um exemplo deste movimento é a construção da Política de Saúde Mental do Estado do Rio de Janeiro, que, desde março de 1999, tem como principal diretriz de ação a reorientação do modelo assistencial hospitalocêntrico, criando uma rede de serviços de pequena e média complexidade para atendimento psicossocial no território.

Com base nos indicadores clínicos, epidemiológicos e de organização dos serviços, além dos indicadores sociais em geral, a Assessoria de Saúde Mental encaminhou aos gestores municipais o Plano de Implantação da Rede de Atendimento Psicossocial, centrado nos Centros de Atenção Psicossocial (CAPS) como dispositivo estratégico, capaz de funcionar como centro articulador, em uma lógica de rede, das instâncias de cuidados básicos em saúde, incluído o Programa de Saúde da Família, rede de ambulatórios, atendimento terciário (internações) e atividades de cuidado e suporte social como, por exemplo, lares abrigados, trabalho protegido, lazer, advocacia de direitos e de questões previdenciárias. Atualmente, mais de 90\% dos municípios do Estado já apresentam seus Programas Municipais de Saúde Mental em funcionamento.

Embora ainda haja um longo caminho a ser percorrido, podemos afirmar que é inconteste o avanço obtido: surgem os primeiros CAPS em áreas historicamente desprovidas de bens e serviços, e está em curso a implantação de uma série de serviços tipo oficinas terapêuticas I e II em vários municípios de pequeno porte no interior do estado. As Residências Terapêuticas já estão em funcionamento em alguns municípios, e têm início várias ações que visam resgatar a contratualidade desta clientela. Outros estados como, por exemplo, São Paulo e Rio Grande do Sul, também estão em processo de implantação desse novo modelo assistencial.

Verifica-se, também, a criação e implantação de mecanismos de controle e avaliação da rede hospitalar pública e contratada, e o estabelecimento de um diálogo permanente com a sociedade, a partir dos conselhos distritais e municipais de saúde, e, ainda, das diversas Associações. Pela primeira vez na história dos programas públicos de saúde mental do país, foi aprovada na Comissão Intergestores Bipartite, uma resolução que aprova a reorientação dos recursos financeiros gastos no sistema hospitalar (SIH) redirecionando-os para o sistema ambulatorial, com vistas a acelerar a implantação da rede de atenção psicossocial nos municípios.

Enfim, há um esforço em direção à implantação de uma política de saúde mental que, de fato, promova mudanças no uso e na gestão dos recursos e potencialidades dos territórios, afirmando coletivamente que a responsabilidade pelo cuidado é uma prática de vários agentes, instituições, sistema de saúde e sociedade.

Pedro Gabriel Godinho Delgado Maria Paula Cerqueira Gomes

Departamento de Psiquiatria e Medicina Legal, Universidade Federal do Rio de Janeiro.
Evandro da Silva Freire Coutinho

Departamento de Epidemiologia e Métodos Quantitativos em Saúde, Escola Nacional de Saúde Pública, Fundação Oswaldo Cruz. 


\section{New directions in mental health public policies in Brazil}

Brazil is experiencing a unique moment in the field of public policies in mental health. After more than a decade of review, Act $3.657 / 89$ was passed by Congress and ratified by the President of Brazil on April 6, 2001. The law provides for the protection and legal rights of persons with mental health disorders, in addition to reorienting the country's mental health care model.

Along with the approval of the law, Brazilians joined in celebrating World Health Day on April 7, this year focusing on the motto Stop Exclusion: Dare to Care. The day was marked by a series of events throughout the country, resulting from efforts by States and municipalities to establish an equitable, inclusive, extramural, and community-based mental health policy nationwide.

Within this context there emerged a strong coalition of State and municipal mental health coordinators, committed to creating the necessary technical and political conditions to guarantee the right to treatment and to the organization of an integrated health care system through the health and sociocultural measures to integrate various dimensions in individuals' lives.

An example of this trend is the establishment of a mental health care policy in the State of Rio de Janeiro whose main thrust since March 1999 has been the reorientation of a hospital-centered mental health care system, creating a network of small and mediumsized services to provide psychosocial care within their respective territories.

Based on clinical, epidemiological, and social indicators and data on the organization of mental health care services, the Mental Health Care Advisory Board submitted its Plan for the Implementation of a Psychosocial Care Network to municipal health managers, focusing on Centers for Psychosocial Care as a strategic device capable of functioning as a hub (within a network logic) for the various levels of basic health care, including the Family Health Program, a network of outpatient clinics, tertiary care (for hospitalization), and social care and support activities like shelters, protected work, leisure, advocacy, and social security issues. Currently, over $90 \%$ of the municipalities in the State of Rio de Janeiro already have Municipal Mental Health Care Programs in operation.

Although much remains to be done, considerable progress has already been made: the first Centers for Psychosocial Care have been set up in areas that have traditionally lacked mental health care infrastructure and services, and a series of type I and II therapeutic workshops are now being implemented in various small municipalities in the interior of the State. Therapeutic homes are already functioning in various municipalities, and activities are in place to safeguard the contractual nature of this clientele. Other States of Brazil, like São Paulo and Rio Grande do Sul, are also in the process of implementing this new mental health care model.

Mechanisms to monitor and evaluate the network of public and outsourced private hospitals have also been implemented, together with an on-going dialogue with civil society based on local and municipal health councils and various associations. For the first time in the history of public mental health care programs in Brazil, a Bipartisan Inter-Managerial Commission has been created through a resolution providing for redirecting public spending from the hospital system to out-patient care, with a view towards speeding up the implementation of a psychosocial care network at the municipal level.

In short, there is a thrust towards implementing a mental health policy which actually promotes changes in resource use and management at the State and municipal levels, collectively affirming that the responsibility for mental health care is shared by various health care institutions, the health system, and society as a whole.

Pedro Gabriel Godinho Delgado Maria Paula Cerqueira Gomes

Departamento de Psiquiatria e Medicina Legal, Universidade Federal do Rio de Janeiro.
Evandro da Silva Freire Coutinho

Departamento de Epidemiologia e Métodos Quantitativos em Saúde, Escola Nacional de Saúde Pública, Fundação Oswaldo Cruz. 